\title{
Secularization - an empirically consolidated narrative in the face of an increasing influence of religion on politics
}

Gert Pickel'

\begin{abstract}
With this research Gert Pickel proposes an updated version of secularization's narrative, contrasting it with the growing phenomena of religious pluralism, secular-religious polarization, and religiosity's politicization in Europe. This article focuses especially on the European religious landscape of the late twentieth and early twenty-first century, analyzing the empirical developments in its indices of secularization, namely at the individual level. For this purpose, the author calls upon several statistical data that consider individuals' attitudes towards religion, bearing in mind the different levels of modernization, as well as the political, religious and historical-cultural vicissitudes of the different countries. Despite religious affair's proliferation in public debate, this article concludes that secularization remains empirically more convincing than the narrative of the return of religions. However, we are still far from speaking of a secular Europe.
\end{abstract}

Keywords: Secularization. (Re)Politicization of the religious. Europe.

\section{Introduction - Europe between the secularization and politicization of the religious}

If we look at religion, recent debates are characterized by two overlapping - and yet apparently essentially antithetical - narratives. On the one hand, reference is made to the social loss of importance of religion (BRUCE, 2002; NORRIS; INGLEHART, 2004; PICKEL, 2009, 2013; POLLACK, 2003; POLLACK et al., 2012). However, this narrative of secularization has been challenged in the last decades by the narrative of a return of the religious or

Professor de Sociologia da Religião na Faculdade de Teologia da Universidade de Leipzig (Alemanha). 
of religions. ${ }^{2}$ Such a narrative often regards secularization as a false, or at least a short-sighted, interpretation of contemporary developments (CASANOVA 1994; LUCKMANN, 1967), and even sometimes sees secularization theory as fundamentally outmoded (STARK, 1999; STARK; FINKE, 2006). Especially the (increasing) visibility of public debates on religion (CASANOVA 1994) and a seemingly increasing spiritualization of Western societies (HEELAS; WOODHEAD, 2005; STOLZ et al., 2016) are seen as arguments for the end of the narrative of secularization, with Casanova (2009) describing secularization as a "modern myth", one that belongs primarily to European discussion and history.

Even if the opposing narrative of the return of the religious has quickly gained wide acceptance in public and academic domain, there still appears to be a question, that has not yet been decided once and for all: namely, which developmental direction can better describe in a way that is as close to reality as possible the present changes undergone by the religious and the significance of these changes to the political sector? It therefore did not take too long before the empirical validity of the narrative of a return of the religious was questioned (POLLACK, 2009; PICKEL; SAMMET, 2012). In addition, secularization theory has been modified. While Norris and Inglehart (2004 also PICKEL, 2009, 2011; POLLACK; ROSTA, 2015) argue for a path-dependent secularization theory, the tradition represented by Shmuel Eisenstadt (2002) maps out "multiple secularities" (BURCHARDT; WOHLRAB-SAHR, 2013; BURCHARDT; WOHLRAB-SAHR, M.; MIDDELL, 2015), i.e., different paths to different forms of secularity. Such diversity raises the following question: which narrative is now most appropriate to describing the reality of the present in the modern societies of Europe?

My opinion is that the answer should go beyond a simple decision for one or the other side, and I would like to present three theses:

1. Europe is characterized by a general process of (path-dependent) secularization, one linked to processes of pluralization, in the sense of an increase in religious and secular groups and options.

2 Different patterns of argumentation concerning the return of the religious (regarding increasing spirituality and the transformation into new, private forms of the religious) and the return of religions (in the sense of a gain in the public relevance of (world) religions elsewhere) are often mixed together here, even though they address different aspects. 
2. Both processes are accompanied by tendencies of a polarization between secular and religious positions or actors, as well as between social groups of different religious character.

3. Within polarization, there is, despite a further advancing secularization, also a gain in the importance of religion (only) in discourses in the public and political sector, in the sense of a politicization of religiosity.

Since the discursive opposition between both narratives has been fixed on the European context, it is worthwhile focusing our attention on Europe, too. Nowhere else in the world is the development of secularization so intensely discussed as in Europe. ${ }^{3}$ Nowhere else can we find such advanced empirical findings that point to secularization. And nowhere else has a stage of modernization already been reached that allows in the first place for a process dependent on modernization to emerge such as secularization. ${ }^{4}$ But nowhere else is reference made to a return of the religious and of religions in an attempt to call into question the universal validity of secularization. And nowhere else is the effect of religious developments on the political domain so interesting. It had become common practice there to consider, with regard to religious freedom, the increasing separation of church and state as indicating the declining influence of religion on politics. It was only when religion once again entered into political debates that the view changed in a number of respects - and the narrative of secularization was called into question. Narratives are now meaningful stories that can be tested for their validity only with regard to reality, and this is what I intend to do here by analyzing the empirical development of the religious in Europe. To do so, I use various survey data that consider people's attitudes to religion in many different ways. ${ }^{5}$

3 Even though the debate on political secularism may well have a broader focus (FOX, 2015).

4 The background is that secularization theory hardly expects extensive processes of secularization in areas with a low level of modernization (if we can use such a term without being ethnocentric). The economically aspiring states of Southeast Asia can alone serve as a litmus test for the assumption that there is a link between modernization and secularization (POLLACK, 2016, p. 82-91).

5 A similar argumentation in German is used in Pickel (2017). 


\section{Theoretical reflections on the development of religiosity}

Recourse to theoretical explanatory models in the sociology of religion has its utility in the conceptual embedding of empirical analysis of developments undergone by religion and religiosity. If certain theories prove to be more, and others less, valid, then this would allow at best a glimpse into what might happen in the future. The focus of theoretical explanations has condensed in recent decades, and there are now three models offering alternative ways of explaining the religious (Figure 1 - also PICKEL, 2009, p. 90-95, 2011, p. 135-225; POLLACK, 2009, p. 19-59; POLLACK; ROSTA, 2015, p. 25-87). We can assign them quite easily to the two narratives mentioned above. There is on the one hand secularization theory, which for a long time dominated interpretation in this area (SWATOS; OLSON, 2000). It assumes a social loss of importance of religion, resulting from, or accompanying, a more general process of modernization (BRUCE, 2002; POLLACK, 2016). Besides rationalization, which has spread since the Enlightenment, it is above all the processes of functional differentiation, of urbanization, but also of the continuing growth in prosperity, that makes religion less relevant to the social existence of modernizing societies, and even apparently superfluous for some people (NORRIS; INGLEHART, 2004, p. 215-242). Secularization therefore, is bound tightly to the social and socio-economic context (PICKEL, 2013); it is driven by multiple factors; and, third, it is a slow process (BRUCE, 2002 also VOAS, 2008). The concept of secularization describes in its basic definition not the complete disappearance of individual religiosity, but only its decline in importance for functions in society. However, since secularization theorists assign importance to underlying social conditions, they do find plausible the effects of a more general social loss of importance on subjective religiosity. If religion becomes less socially important, then people's own religiosity will also probably lose relevance for how they structure their own everyday lives. At the very least, there will be fewer factors that encourage or revive a subjective religiosity. Since religious socialization takes place relatively early and arises from a certain stability in life, a break with personal religiosity and religious vitality takes place mainly through generational change (NORRIS; INGLEHART, 2004, p. 13-15). This claim has very much established itself in secularization theory (POLLACK, 2016, p. 67-98), and leads to the further 
claim that, if modernization continues, then the degree of secularity in a society will also increase from generation to generation.

\begin{tabular}{|c|c|c|c|}
\hline & $\begin{array}{c}\text { Secularization } \\
\text { Theory }\end{array}$ & $\begin{array}{c}\text { Theory of } \\
\text { Individualization }\end{array}$ & $\begin{array}{c}\text { Theory of Pluralization } \\
\text { and Vitalization }\end{array}$ \\
\hline Authors & $\begin{array}{l}\text { Brian Wilson } \\
\text { Steve Bruce } \\
\text { Peter L. Berger }\end{array}$ & $\begin{array}{c}\text { Thomas Luckmann } \\
\text { Grace Davie } \\
\text { Danielle Hervieu-Léger }\end{array}$ & $\begin{array}{c}\text { Rodney Starke } \\
\text { Roger Finke } \\
\text { Laurence lannaccone }\end{array}$ \\
\hline Basic Thesis & $\begin{array}{c}\text { General differences } \\
\text { between Modernity } \\
\text { and Religion lead to a } \\
\text { consisting decline of } \\
\text { the social significance } \\
\text { of religion }\end{array}$ & $\begin{array}{l}\text { Institutionalized religion } \\
\text { can lose significance, } \\
\text { but because religious } \\
\text { beliefs of man are } \\
\text { an anthropological } \\
\text { constant, only a chance } \\
\text { in forms of religiosity } \\
\text { appear }\end{array}$ & $\begin{array}{l}\text { There is a constant } \\
\text { demand for religiosity and } \\
\text { religious beliefs. Therefore } \\
\text { the level of religious } \\
\text { vitality depends from } \\
\text { the supply of religious } \\
\text { products on the religious } \\
\text { market }\end{array}$ \\
\hline $\begin{array}{c}\text { Relation to } \\
\text { general theory }\end{array}$ & $\begin{array}{c}\text { Modernization } \\
\text { Theory }\end{array}$ & $\begin{array}{c}\text { Theory of } \\
\text { Individualization }\end{array}$ & $\begin{array}{c}\text { Rational-Choice and } \\
\text { Market Theory }\end{array}$ \\
\hline Projection & $\begin{array}{l}\text { Continuous decline of } \\
\text { all forms of religiosity }\end{array}$ & $\begin{array}{l}\text { Decline of involvement } \\
\text { in churches, but constant } \\
\text { or increasing individual } \\
\text { religious beliefs }\end{array}$ & $\begin{array}{l}\text { Development of religiosity } \\
\text { in relation to freedom and } \\
\text { expansion of a religious } \\
\text { market in society }\end{array}$ \\
\hline
\end{tabular}

\section{Figure I - Fundamental Lines of Thought in Contemporary Sociology of Religion}

Source: Own composition, see also Traunmüller (2009, p. 67) and Pickel (2009, p. 90-94).

Followers of individualization theory reject the claim that institutional processes of secularization "colour" personal religiosity. Theircentral justification is the existence of personal religiosity as an anthropological constant of human life: we can hardly be human without the ability to transcend (LUCKMANN, 1967), which makes a decline in subjective religiosity impossible. Followers of this approach have few problems accounting for the church's social loss of importance and a decline in churchliness. They see this specific expression of a "fundamental transcendence" as also being subject to erosion in modern societies. This commonality with secularization theory often leads followers of 
the market model of the religious to classify them as secularization theorists. But they see themselves as being different to and distant from secularization theory, since they regard the process that can now be observed as being not one of secularization, but one of the transformation of the religious. With the growing range of offers on the religious market, and the expansion of what can be considered religious, there have emerged mixed religiosities and new, but private, forms of the religious. There is, then, no decline of religiosity, but only of (Christian) churches. This approach also emphasizes a return of the religious, but only insofar that precisely this form of alternative religiosity was hitherto invisible to researchers (also because of its privateness). It was only the recognition by observers of the new forms of the religious (and spiritual) that enabled the idea of a return. Individualization theory does nonetheless help to extend the narrative of a return of the religious, while at the same time emphasizing the revival of spiritual or experiential forms of personal religiosity in the individualistic modern period. ${ }^{6}$

Supporters of the market model of religion focus on how religious vitality depends on what is available on an open religious market (STARK; FINKE, 2006; STARK; IANNACCONE, 1994). The basic assumption of this approach is (similar to individualization theory) that there is a constant demand for religious goods. Every person is essentially religious and is in search of what is for him or her the most suitable and exclusive religious goods. For the market model, which is based on rational-choice theory, religious vitality is comprised primarily of religious actions, and varies solely according to the form of the religious goods on offer. A varied and broad range of goods is best suited to satisfying the increasingly pluralizing and exclusive interests of believers in the modern period. This is most likely to occur when there is a situation of religious competition that is as free of state influence as possible. What is problematical is when the state restricts the religious market, something that occurs in its most rigid form when there is a state religion. Detrimental to this free market and the religious vitality of a society are a traditional preference for individual religions in certain countries and a close link between state and church. In general, this model claims an advancing pluralization of the religious landscape (which goes

6 This is most evident in the propagation of a "spiritual revolution" (HEELAS; WOODHEAD, 2005). 
hand in hand with modernization). The search for exclusive offers provides good opportunities for exclusive and attractive suppliers that have a clearly defined profile. This includes the goal on the part of the social groups tending towards these suppliers of a strong identity formation at the collective level, with this identity formation being determined by clear and sometimes rigid demarcations. Such an identity comprises a strong concept of togetherness with allegiance and a strong affective attachment to the group. At the same time, it is a model of religious identity that to a certain extent opposes, through its limited openness, concepts of a people's church. For the market model, such concepts are not in a position to develop exclusive offers, since too wide a spectrum of church members adhere to them. As far as the market model is concerned, an individualistic understanding of religiosity risks isolating the individual and therefore appears to be unable to describe current developments of the religious. The return of religion, both of the religious (increasing religious vitality) and of religions (the spread and attractiveness of different faiths), is the result of the expansion made necessary by the market of the range of religious goods on offer. New suppliers enter the market, occupy the available niches, and increase with their new goods the whole religious vitality of the population.

\section{Levels of secularization as a conceptual starting point of investigation}

The narrative of the return of religion (to make a pragmatic summary of both tendencies: a return of the religious and a return of religions) is based on a differentiation from secularization theory (POLLACK, 2016, p. 70-76). To investigate the empirical validity of the narrative, we need to examine the theory of secularization with regard to its premises. The advantage of doing so is that it does justice to the distinctness of this theory and to the different processes and objects with which it is concerned. This avoids jumping to conclusions based on a criticism of secularization theory, as was still justifiable in the early 1970 s. $^{7}$ It is helpful here to distinguish between the sub-processes of secularization. Dobbelaere (2002, p. 29-126) differentiates between social,

Typical of this is the radical criticism by Stark (1999) or Swatos and Cristiano (1999). On criticism of secularization theory and its validity, see Pickel (20II) and Tschannen (199I). 
organizational and individual secularization. ${ }^{8}$ José Casanova (1994) makes a similar distinction between possible levels of secularization. The first dimension used by Casanova (separation of church and state) overlaps with Dobbelaere's dimension of social secularization, while Casanova's second dimension (loss of faith) overlaps with Dobbelaere's dimension of individual secularization. Casanova assigns an independent (third) dimension to the argument of the withdrawal of religion into the private sphere, which he contradicts on account of his thesis that religion has gained in importance for public discourse. Combining both models gives rise to the levels of secularization shown in Figure 2.

\begin{tabular}{lc}
$\begin{array}{l}\text { Level of secularization } \\
\text { (or return of religion) }\end{array}$ & Mechanism \\
\hline $\begin{array}{l}\text { Social secularization } \\
\text { As a consequence of the functional differentiation typical of modern } \\
\text { societies, religion loses its function for society (social norms, } \\
\text { integration, upbringing) }\end{array}$ \\
$\begin{array}{l}\text { Organizational } \\
\text { secularization }\end{array}$ \\
$\begin{array}{l}\text { Adaptation of religious communities to present market structures } \\
\text { and internal secularization, or change to network-like structures } \\
\text { secularization of religion in the sense of a change to the social } \\
\text { formation and to the self-perception of churches (rationalization) }\end{array}$ \\
\hline $\begin{array}{c}\text { Process of increasing distancing of people from religion, decline } \\
\text { in membership, in church integration, and in subjective religiosity } \\
\text { linked to an erosion of subjective religiosity }\end{array}$ \\
\hline $\begin{array}{c}\text { Public secularization } \\
\text { in the discursive engagement with religion and religious issues in } \\
\text { the public sphere (speeches on religion, religious communication) }\end{array}$ \\
\hline
\end{tabular}

Figure $\mathbf{2}$ - Levels of secularization

Source: My own overview; see also Pickel (2013, p. 77).

8 The distinction between levels in the work of Casanova and Dobbelaere directs our attention to processes - that is, to secularization and not secularity. Together with different contextual factors, the effects of such processes work indirectly on the "actual religious inventory". We should therefore formulate a statement about a society that is precise: a secularizing society is still very different from a secular society. We should also specify clear criteria to determine whether a society is secular and where the threshold for this applies. 
Social secularization denotes the process of functional differentiation typical of modern societies. This process entails a loss of function of religion for society, a loss arising from the differentiation of new responsibilities for areas of society for which religion was once responsible. The separation of politics and religion falls into this area. Organizational secularization denotes the decline of religious communities and the process of the inner secularization of religion, in the sense of a change to the social form and self-perception of churches (rationalization). Individual secularization denotes the process of the increasing distancing of people from religion, a process that comprises the decline in membership and in subjective religiosity and its personal significance in everyday life. The level of public secularization denotes the decline in the discursive debate with religion and religious issues in the public sphere (religious communication).

Public secularization can develop in different ways. On the one hand, according to Casanova (1994), there may be a shift in discussions between politics and religion from the political-institutional sector and into the sector of civil society. This would then be less a secularization than a shift in the level of discussion - or in the political arena where the debate with religion takes place. Here, importance is gained by the large number of civil-social associations around the churches that have a religious background (PUTNAM; CAMPBELL, 2010; PUTNAM, 2000; PICKEL; GLADKICH, 2012). However, the question remains open as to whether the civil-social institutions with religious visibility can also not be exposed to individual secularization. One conclusion would be that, in the case of a shift in the religious structure of society into civil society, only social volunteer networks that no longer have any religious character will at some point remain. Individual secularization would then be primarily responsible for such a state.

These reflections suggest that we should consider the discussion about the validity of the narrative of secularization, or of the return of religion or of the religious, in a differentiated way according to levels, if we wish to draw convincing conclusions about the future development of the relationship between religion and politics. Thus, both cases often argue at different levels, and it is not impossible for seemingly contradictory processes to occur side by side or simultaneously. At the same time, processes at one level can be 
temporally superimposed on other processes (secularization can precede the other process), and they can also affect one other. This effect does not always necessarily only reinforce the other processes, with social secularization in the sense of the separation of church and state being able to promote individual secularization, but also just as much constituting the prerequisite for processes of individual revitalization. The same is also possible for the link between the level of public discourse and the individual level. If an increased discussion about religion can activate the willingness of believers to advocate it, then negative connotations in such discourses are likely to have the opposite effect.

\section{Indices of secularization and their justifications}

Let us begin with social secularization. The last few decades have witnessed an increasing unbundling of relations between church and state in Europe, at least as far as institutional relations are concerned. But that should not lead us to believe that a complete functional differentiation has taken place. We can very well speak here of secularization at the institutional level, without the state of secularity having also almost been reached at some other level. This applies to highly religious countries such as Poland and Italy, as well as to Estonia, Great Britain and the territory of East Germany. If we also add the reflections on regulating and supporting religion, then we can still see the essential role played by religious actors in the political process. ${ }^{9}$ However, institutional interdependence is only one side of the coin. How do citizens see it? The attitude towards the functional differentiation of politics and religion is clear for Europe: even in countries with a strong religious majority, most of the population regard institutionalized politics and religion as separate spheres (Figure 3). ${ }^{10}$ They reject the exertion of influence by religious leaders on political and governmental decisions, and the same answers also applies, incidentally, to the influence of religious leaders on elections, which is not shown separately in the text.

9 Which may differ from developments outside Europe of a potentially increasing mutual interdependence of state and church (FOX, 2015).

10 This is also (still) the case for Turkey at the time of the survey 2013. It remains to be seen after the latest developments how far a religious population and a functional separation of politics and religion are in harmony with each other. 


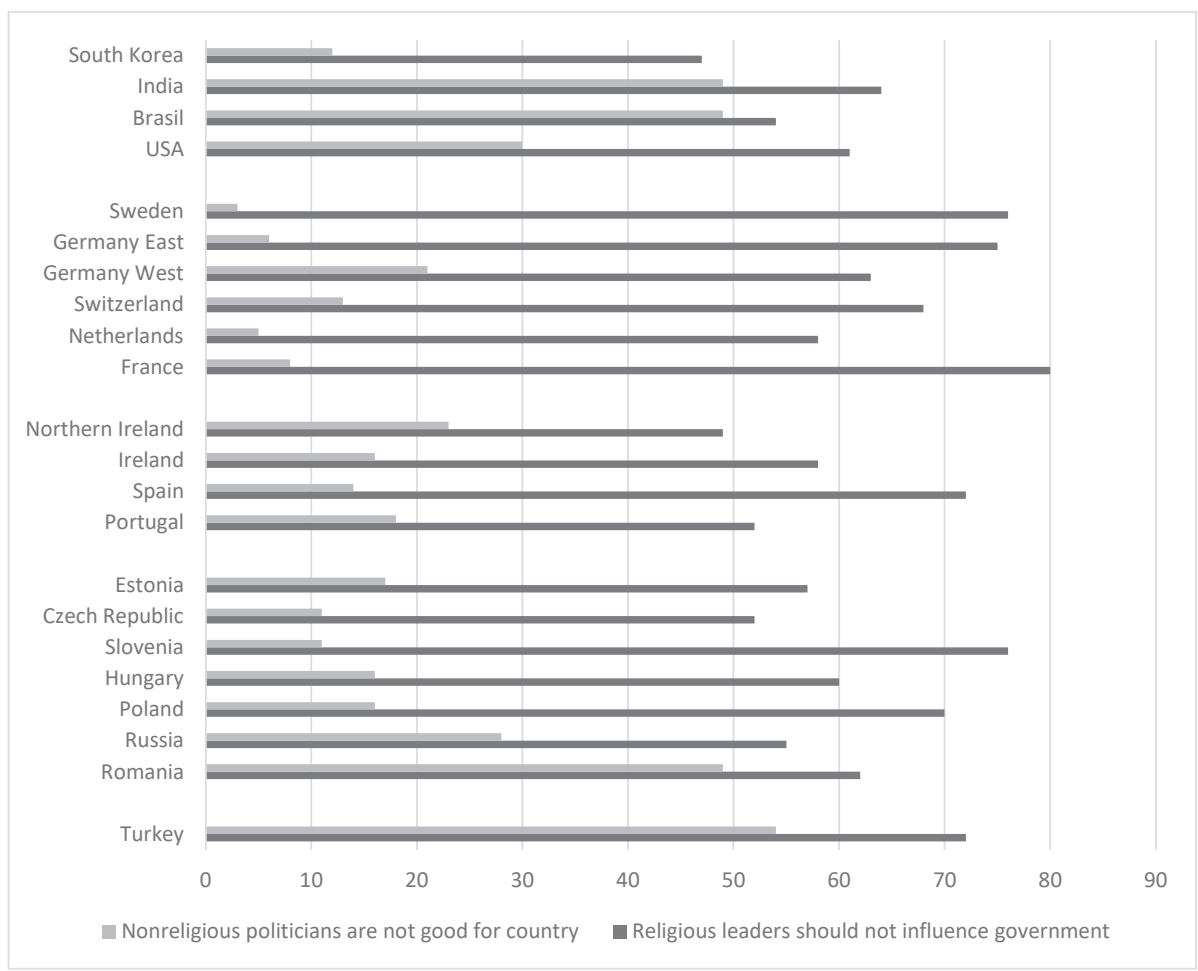

\section{Figure 3 - Societal Secularization: Religion and Politics in the minds of the people}

Source: Own calculations, European Values Surveys 2008/World Values Surveys 2006-2008; "Religious leaders should not influence decisions of the government"; agree and strongly agree of four options; $n=1000-2000$.

This preference for the functional differentiation of social spheres does not necessarily mean that religious people should not be active in politics. On the contrary, personal religiosity is in some countries almost a prerequisite for being a good politician for quite a few respondents. Such people probably do not expect their own religious interests to be represented necessarily, but think that these representatives will have moral integrity. There are at this point now clearer differences in Europe than in the previous question. The separation of religion and politics is widely anchored in the populations of Western Europe. Especially in laicist France and the Netherlands, there are very few citizens who think that a politician should be religious or believe in God to 
do his or her work well. This proportion changes when we move to the east of Europe, and especially to countries with a majority Muslim population. For instance, more than half the population of Turkey believed in 2008 that a politician should be a religious person. In 2001, that figure had even been 61 percent. If we look beyond Europe, this premise is met with great approval in other religious countries, and not just in the Arab world. If we bring these results together, then social secularization is widespread in Europe, and in Western Europe it is almost common sense. Following Casanova (1994), who argued in an earlier position that the functional differentiation of politics and religion is the only process of secularization that is allowed to be universal and unchangeable, functional differentiation and modernization seem to go hand in hand (POLLACK; ROSTA, 2015, p. 73-81, p. 380-381; also POLLACH et al., 2012). Europe differs from other areas of the world, though not all, when it comes to the personal religiosity of politicians. Social secularization and the importance of personal religiosity for political action are therefore not mutually exclusive; in Western Europe, they largely go together.

Organizational secularization refers to the self-image and the selforganization of religious communities. These, too, are not separate from their environment. Arguments about the positions that churches take on sociopolitical matters show that changes take place with regard to overall social change. Sometimes, the concept of self-secularization is used with regard to organizational changes in the direction of modernization. The extent to which a change in the form of churches should correspond to this concept is vague. But, moral-political issues are also becoming more controversial in the population and politics of Europe. Religiously based positions on morality can no longer simply depend on majority support among the population of Europe, but are the subject of discussion in society. There is an increase in controversy here in the views on relevant questions, between political secularists, people who are secular, and representatives of religious communities and religious people. This controversy now has a considerable effect in religious communities, which are balanced between adapting to new values and norms, and a politically formulated position of rejection.

It is at the level of individual secularization that the different interpretations offered by the two narratives clash most intensely. Here, the claim that the social loss of importance of religion will continue into the area of personal religiosity is opposed by a contrary development. This development can be characterized on the one hand as a shift of the religious 
into the private sphere; and, on the other, following Casanova (1994), as an independent development of personal religiosity and religious vitality due to the competitiveness of religious communities. Individual religiosity is actually excluded from the framework of classical secularization theory. But, entirely in line with the current understanding of the narrative of secularization, most secularization theorists today assume that, because of the impact of underlying social conditions, a social loss of importance also has an effect on personal religiosity. There is relative agreement that two components should be distinguished conceptually: on the one hand, churchliness and allegiance to a religious community, and, on the other, subjective, personal, private religiosity.

\begin{tabular}{|c|c|c|c|c|c|c|c|c|}
\hline & $\begin{array}{c}1990 \\
(1991)\end{array}$ & $\begin{array}{l}1995- \\
2000\end{array}$ & $\begin{array}{c}2004 \\
-2012\end{array}$ & & 1990 & 1991 & $\begin{array}{l}1995- \\
2000\end{array}$ & $\begin{array}{l}2004- \\
2012\end{array}$ \\
\hline Italy & 15 & 12 & 18 & Poland & 4 & 4 & 4 & 4,5 \\
\hline Portugal & 8 & 8 & 12 & Lithuania & 42 & 26 & 17 & 15 \\
\hline Spain & 15 & 16 & 21 & Slovak Republic & 22 & 22 & 15 & 17 \\
\hline Cyprus & - & - & 4 & Slovenia & 29 & - & 32 & 38 \\
\hline Ireland & 4 & 6 & 7 & Hungary & 45 & 37 & - & 46 \\
\hline France & 39 & 40 & 44 & Croatia & - & - & 12 & 5 \\
\hline Luxemburg & 9 & 17 & 30 & Czech Republic & - & 59 & 63 & 73 \\
\hline Belgium & 28 & 30 & 44 & Germany East & 65 & - & 68 & 74 \\
\hline Austria & 12 & 12 & 15 & Latvia & 74 & 44 & 37 & 34 \\
\hline Netherlands & 49 & 53 & 58 & Estonia & 92 & 65 & 74 & 70 \\
\hline Switzerland & 12 & 11 & 18 & Romania & 6 & 2 & - & 1 \\
\hline Germany West & 11 & 15 & 18 & Bulgaria & 68 & 37 & 32 & 22 \\
\hline United Kingdom & 44 & 48 & 52 & Macedonia & - & - & 12 & - \\
\hline Northern Ireland & 11 & 14 & 19 & Serbia & - & - & 14 & 4 \\
\hline Sweden & 23 & 28 & 26 & Russia & 68 & 57 & 47 & 38 \\
\hline Denmark & 9 & 11 & 12 & Belarus & - & - & 43 & 28 \\
\hline Norway & 11 & 10 & 10 & Ukraine & - & - & 40 & 26 \\
\hline Finland & 12 & 12 & 18 & Georgia & - & - & 9 & 2 \\
\hline Iceland & - & 4 & 4 & Moldavia & - & - & 16 & 6 \\
\hline Greece & 3 & 3 & 6 & Albania & - & 6 & - & - \\
\hline Turkey & 4 & 4 & 2 & Bosnia-Herz. & - & - & 27 & 23 \\
\hline
\end{tabular}

Figure 4 - Individual Secularization: Non-membership - in Europe mostly a rising category

Source: Own calculations with different data-sources (Z.B. WVS, EVS, ISSP,

Aufbruch, CER); in percent; $n=1000-2000$ per country (PICKEL, 20II). 
The dimension of allegiance shows: (1) Clear differences prevailing in Europe as far as the level of irreligiosity is concerned. Cultural traditions and underlying political conditions shape the environment of religion and thus the dimension of allegiance (MARTIN, 1978; PICKEL, 2011, p. 225227). Just as Catholicism appears to provide more favourable conditions than Protestantism or a mixed religiosity when it comes to consistency of allegiance, so the political embedding of religion and the level of modernization affect allegiance to a religious community - or precisely non-allegiance. (2) There is in Western Europe a continuing increase in the number of irreligious people. This is as true for the Eastern European countries with a higher level of modernization as it is for Western Europe (PICKEL, 2009, 2011). In some Eastern European countries, though, there has been a recovery from the low level of membership to which it had fallen in the days of socialism. If we interpret the indicator of allegiance as being significant for secularization, then we must speak of far-reaching secularization processes in Europe. However, these processes do not lead directly and unbrokenly to the distributions of allegiance to religions or irreligiosity. They touch on underlying historical, political and socio-economic conditions. These conditions create pathways for what are otherwise uniform developments (NORRIS; INGLEHART, 2004; POLLACK; ROSTA, 2015). We are therefore dealing here when it comes to allegiances in Europe with a path-dependent secularization (PICKEL, 2011, p. 241-242, 2011, p. 15-16).

Another dimension of the religious is religious practice. Developments here confirm the findings for irreligiosity. Religious practice, in the case of going to church service, has mainly declined in recent decades (PICKEL, 2011). ${ }^{11}$ Growth is moderate even in those Eastern European countries that have experienced a boost in allegiance to a church since 1990. It almost seems as if belonging to the Orthodox Church is already enough for most citizens in Russia - a deeper practice is then no longer necessary for most members. Fluctuations in religious practice between the European countries are again striking. On the one hand, there are systematic signs of cultural and political aspects in line with modernization theory that are already demonstrable in the dimension of allegiance; on the other, though, this is not quite enough to

II A process confirmed by other indicators of religious participation, such as individual prayer and its frequency. 
explain some particularly high levels of practice with regard to church service. Some countries require individual explanations. This applies to Ireland, Poland and Northern Ireland. Especially Northern Ireland is striking, as we find there an enormously high level of attendance at church service - which is especially unusual for Protestant countries. The reason is clear to most readers: we have in Northern Ireland and neighbouring Ireland a political conflict, one that is heavily charged by religious allegiance. Bruce (2002, p. 19) introduces here the thesis of "cultural defence" as an addition to secularization theory. For, when religion is used as the central factor in the construction and revival of identity for nations or communities, then there is a massive (re)awakening of religious vitality. This approach can also be applied to Poland, where the Catholic Church, as a defender of the Polish people, has carried tradition since the time when the Polish state did not exist, through the opposition to communism, and right up to the present day. Similar effects can be observed in most of the successor states of the former Yugoslavia, where the formation of a state community with a collective identity is linked to a closed religious identity. In principle, we should speak of an identitary politicization of religion.

Critics of secularization theory - for a particularly vehement example, see Stark (1999) - often point out that these data on the Christian church and churchliness only provide limited insights into individual religiosity. Is it not rather the case that, in modern, pluralizing and individualizing societies, religiosity manifests itself instead in private, as a mixed religiosity? As plausible as this argument is, it does not seem to be proven by the data. The distributions and developments shown are also found in a comparable manner in indicators of subjective religiosity - Figure 5 - with alternative data (PICKEL, 2011, p. 232). Whether people are asked for their self-assessment of subjective religiosity, belief in God is surveyed, or other indicators of religious experience are considered, the distribution between the countries remains similar to indicators of churchliness, even if, as a rule, the level of subjective religiosity is generally always a little higher than that of religious practice. ${ }^{12}$

12 It is therefore understandable that, under the dimensions of religiosity, the dimensions of religious knowledge and of religious practice should be the first to slip out of view. The much less difficult ideological component of faith (GLOCK, 1965) - which in Western Europe is connected to the widely publicized ideas of individualization - only slips out of view later. 


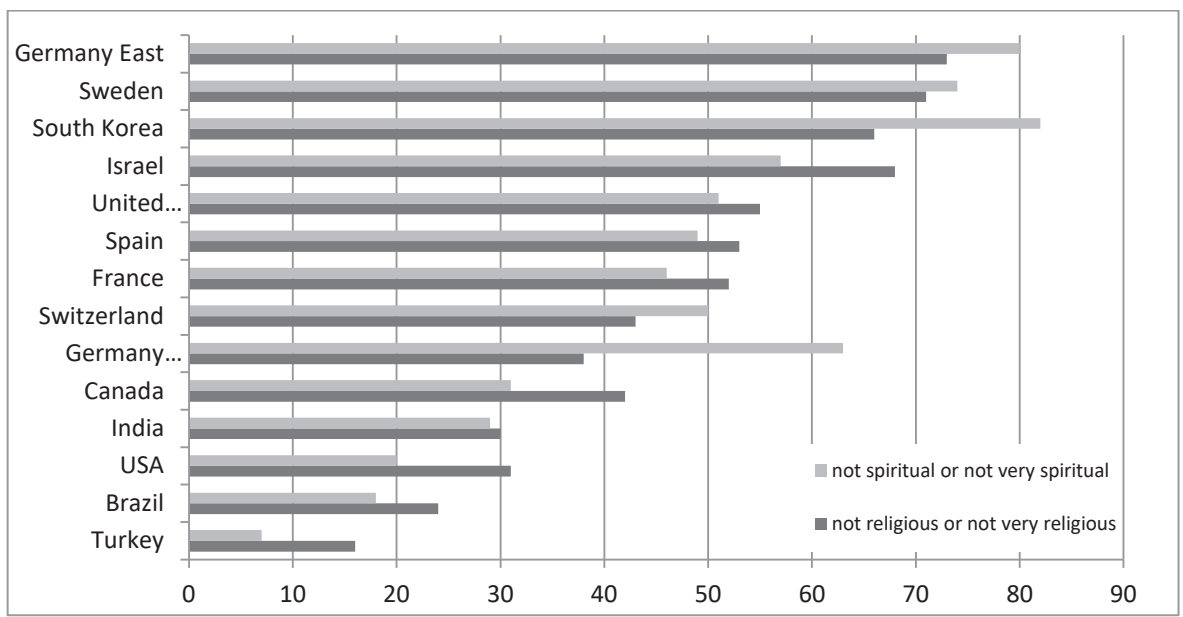

Figure 5 - Individual Secularization: Neither or nor - spiritual and religious

Source: Own calculations, Bertelsmann Religionsmonitor 2013; "peoples self-assessment of (not) religiousness and spirituality - answer no or not much"; n=1000-2000.

With the exception of the "special case of the US", it is mostly the heavily modernized (European) countries that show the least personal religiosity (see also PICKEL, 2011, p. 225-242; MEULEMANN, 2015, p. 31-80; NORRIS; INGLEHART, 2004, p. 83-156; VOAS; DOEBLER, 2011, p. 46-60). At the same time, level of modernization and personal religiosity almost correlate better than level of modernization and allegiance to a religion. This is clear in the case of Sweden, where, after the recent period of state religion, the Protestant Church (still) has a relatively large number of members, but these members seem largely from their own statements to be no longer religious, let alone spiritual. This brings us briefly to a different point: interviewees in most countries hardly distinguish between spirituality and religiosity (which is also confirmed by correlation coefficients of, as a rule, >. 60 in the countries). There is therefore little to suggest a transformation of the religious into a spirituality based more strongly on individual experience. Larger groups of people who define themselves as not religious exist not only in Europe, however. In Israel and South Korea, the latter being an example that is often referred to as showing the rise of Christian religiosity, there are more people 
who regard themselves as non-religious than religious. ${ }^{13}$ Even if we have doubts about how the questions were formed and the reliability of surveys on this subject, we cannot help but take seriously at least to a certain extent the subjective statements of the interviewees. Even when there is a strong cultural foundation, the attitude towards the social construction of "religiosity" does nevertheless express something about the subjective religiosity of individuals.

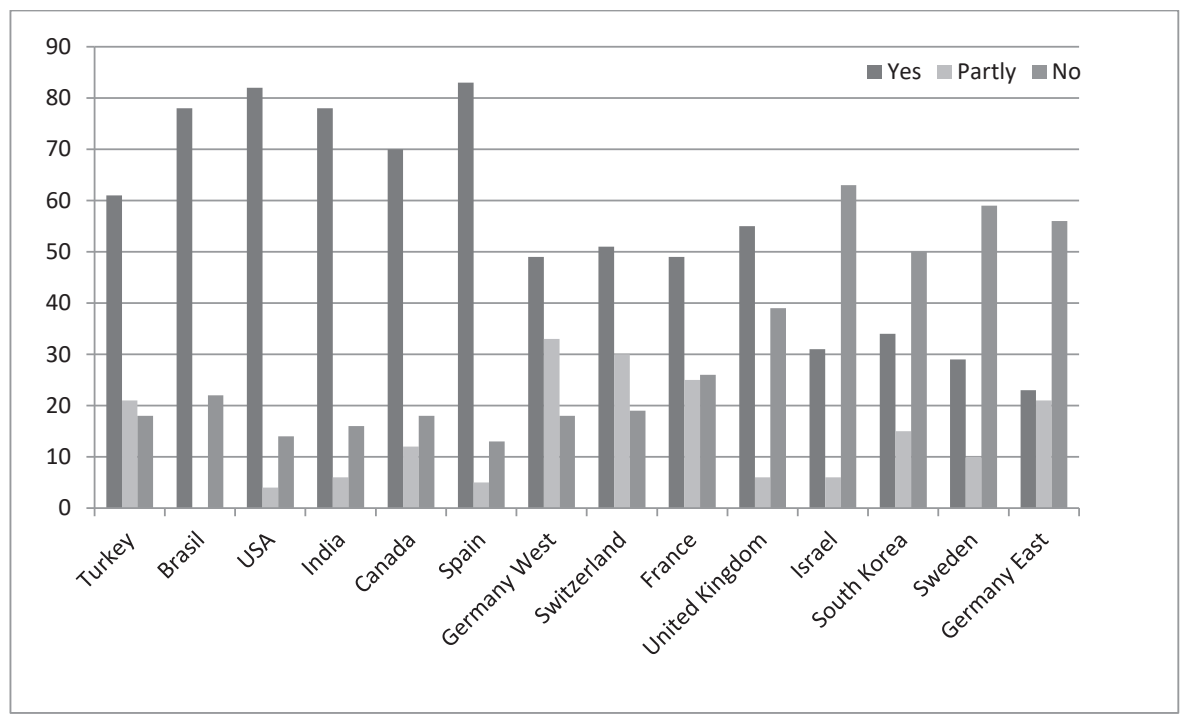

Figure 6 - Individual Secularization: Religious Socialization as main predictor

Source: Own Calculations, Bertelsmann Religionsmonitor 2013;

"Are you brought up in religion"; $n=1000-2000$.

The main reason for this development is socialization, or its discontinuation in the face of advancing modernization. As Figure 6 shows, there is an overlap between the countries where religiosity is currently higher and those in which there is (still) a stronger religious socialization, and vice versa (VOAS; DOEBLER, 2011, p. 46-54 for Great Britain). This is also confirmed by

13 Thus, new data and observations also show that the religious growth of the last two decades has now reached its limits in South Korea and that, besides the effect of organizational competition (POLLACK; ROSTA, 2015, p. 400), secularization processes also seem to have taken hold in parts of South Korean society. 
extremely high internal correlations between religious socialization and all factors of personal religiosity in all countries investigated. In East Germany, Sweden, South Korea, and among a large number of Israeli citizens, religion is no longer something that people pass on, or something that they themselves have been brought up with. This lack of attachment to religion is then expressed in a low level of subjective religiosity and religious practice, and in irreligiosity. What is striking is the sharp break in religious ties that is now taking place in Spain, where the current reappraisal of the Franco past, which places the Catholic Church in a rather negative light, and a great dissatisfaction among young people with the Catholic Church and its mediation of traditional values, reveal a much sharper breaker than is otherwise the case in Europe. Also worth noting is the undecided attitude that people in France, Switzerland and West Germany have towards their own religious socialization, where a remarkable number of respondents cannot decide whether they were, or are no longer, brought up religiously. Religious socialization is in virtually all countries of Europe a process that differs between generations. In every new generation (according to their own statements), fewer people experience a religious socialization than in the preceding generation. A similar picture also emerges with regard to other indicators of religiosity. It is always the younger age cohorts who are less religious than the older age cohorts. The main mechanisms are the change in values and increasing individualization (NORRIS; INGLEHART, 2004, p. 76; POLLACK; ROSTA, 2015, p. 153158). Not only are more and more children no longer required to participate in religious life, which conveys to them its low level of relevance; they also gain the strong impression that religion only has a limited significance for everyday life. ${ }^{14}$ This picture of a lack of relevance to everyday life is spreading increasingly in European societies through generational change. This certainly does not mean the disappearance of subjective religiosity. But an increasing number of people are seeing a religious order to their lives as being subordinate to other premises of life.

The descriptive, but also comparative, findings presented so far have been interpreted quite loosely in terms of the theoretical approaches introduced.

14 The alternative explanation that people become more religious in the course of their lives cannot be rejected entirely, but, according to the few empirical surveys reliable here (LOIS, 20I3), such an explanation clearly has less value than the generational explanation. 
Systematic explanations have been suggested - and were also plausible against the background of the observations. But, since several explanatory approaches are available, we should attempt a somewhat more systematic investigation. This is what I shall now do for the European countries with correlations at the macro level (Figure 7)..$^{15}$ They provide information on the relations between the central macro-indicators and the distribution of indicators of religious vitality. Included in the analysis are indicators not only of allegiance, but also of religious practice and subjective religiosity.

\begin{tabular}{llccc}
\hline & Membership & $\begin{array}{c}\text { Church } \\
\text { attendance }\end{array}$ & $\begin{array}{c}\text { Belief in } \\
\text { God }\end{array}$ & $\begin{array}{c}\text { Subjective } \\
\text { religiosity }\end{array}$ \\
\hline Europe in general & & & & \\
\hline Dummy: Socialist history & -.30 & -.27 & n.s. & n.s. \\
Modernization & n.s. & n.s. & -.48 & -.37 \\
Protestant culture & n.s. & -.39 & -.54 & -.5 I \\
High religious regulation & -.44 & n.s. & +.35 & +.25 \\
Grade of religious pluralization & n.s. & n.s. & n.s. & n.s. \\
\hline subgroup: no socialist history (Western Europe) & & & \\
\hline Modernization & -.50 & -.54 & -.65 & -.73 \\
Protestant culture & n.s. & -.53 & -.63 & -.47 \\
High religious regulation & -.5 I & n.s. & n.s. & n.s. \\
\hline subgroup: socialist history (Eastern Europe) & & & & \\
\hline Modernization & -.55 & -.30 & -.60 & -.43 \\
Protestant culture & -.74 & -.34 & -.74 & -.70 \\
High religious regulation & -.43 & $\mathrm{n} . \mathrm{s}$. & +.40 & +.43 \\
\hline Europe in general (controlled) & & & & \\
\hline Socialist history (controlled by & -.43 & -.37 & -.42 & -.28 \\
modernization and protestant culture) & & & &
\end{tabular}

\section{Figure 7 - Macro calculations of religious vitality}

Source: Own calculations, aggregate data 2005/2010; Pearsons

correlations; (controlled) partial correlations.

15 These seem to be justified against a multi-level analysis, since we are interested mainly at this point in theoretical approaches that reveal a contextual effect. There are also doubts about the exclusion of multicollinearities through a lack of differentiation between Western and Eastern Europe, as well as related problems in the number of cases available at the macro level for a multilevel analysis (benchmark 30 cases). 
A first glance at the correlations reveals a surprise: a past in socialist Eastern Europe seems to lead usually to a smaller number of members and a diminished level of attendance at church service, but the subjective religiosity measured now (2010) does not differ between Western and Eastern Europe when we compare aggregates. This is consistent with the observations from the frequency comparisons. Visible practices are therefore more strongly affected by political repression than subjective and individual attitudes. At the time of analysis, there were already some movements back to religion and church. However, we cannot overlook a certain consistency and a path-dependency effect for Eastern Europe. Like cultural differences, political differences in relation to religion also affect the current state of religiosity in the countries. What the correlations also show is that secularization theory can claim empirical evidence for itself, too. The level of socioeconomic modernization, which is used as a proxy for modernization processes, has a significant effect on the indicators of subjective religiosity. The result confirms the assumptions: with a higher level of socioeconomic modernization, the social importance of religion falls. There are no differences shown only for religious practice and the dimension of allegiance. This changes if we examine Western and Eastern Europe separately. Modernization has a dampening effect on religious vitality, both under the premises of a historical suppression of religion and without this socialist past: if we control the other factors of influence, then we can see that the inhabitants of countries with a higher level of modernization are on average less religious than those in countries with a lower level of socioeconomic modernization.

The cultural-religious character of an area also creates differences in religious vitality. Belonging to a country or area with a predominantly Protestant character has a particularly negative effect on all elements of religiosity and churchliness. As a rule, the Catholic Church and some Orthodox Christian churches have succeeded in binding their members to them more tightly. This also applies to Western Europe, but, because of the repression in Eastern Europe, the processes of breaking with the church in the period before 1989 were more rapid. Given this combination of repressive socialism, less resistant Protestantism, and higher levels of modernization compared to its neighbouring countries, it is hardly surprising that East Germany should have had to cope with such massive losses in church affiliation and individual 
religiosity (PICKEL, 2013). The erosion of the Christian faith in East Germany has changed the underlying situation in such a way that no movement back to faith has yet to be seen - and that will probably remain so in the near future. The situation is similar in the Czech Republic and in Estonia. Particularly significant here is the Czech Republic, which has a more Catholic character. Regional effects play a role here. The Czech Catholic Church joined what was for the Czech population "the wrong political side" early on in history, and has actually repeated such misjudgments with every change of system. Historicocultural path dependencies have an influence and have helped create a situation where the Czech Republic now differs greatly in terms of its religiosity from its neighbour of Slovakia, with whom it had once formed a single country.

The correlation between modernization and the social loss of importance of religion (which supports secularization theory) is one such path dependency. It has contributed significantly, though not solely, to the current distribution of religiosity and secularity in Europe - and is still contributing to it. Thus, the trends presented in this chapter show a general secularization process built on traditional underlying conditions. Apart from a few Eastern European countries, the narrative of secularization can draw on a broad empirical foundation - precisely as a path-dependent secularization. It occurs in the different dimensions in a graduated way and not simultaneously. Thus, secularization is a narrative that is largely empirically verified and verifiable. However, it needs to be strongly reconnected to concrete cases and their underlying social, cultural and political conditions. ${ }^{16}$ We should bear in mind a premise from the social sciences: social occurrences should be explained from other social occurrences.

\section{The return of religions into the public domain and its reasons}

Against the background of these findings, what now speaks for the narrative of a return of religion? A comprehensive (re)spiritualization instead of a distance from religiosity (return of the religious) occurs as seldom as

16 Which in itself is not a new insight. In as early as 1978, David Martin defined three components to determine the spread of religiosity. 
a massive increase in the number of religious people in Europe (return of religions). Norris and Inglehart (2004, p. 217) express this as follows: "Europe is becoming more secular, and the world more religious". This development outside Europe can be traced much more strongly back to favourable developments in birth rates in strongly religious areas in Africa and Asia than it can to gains made by active missionary work. And also in the much-cited example area of Latin America, there are considerable restrictions to be made regarding a return of the religious, where on the one hand the Pentecostal Churches and Evangelical groups are gaining, while on the other the number of Catholics is falling drastically - and the number of irreligious people is growing slowly. ${ }^{17}$ Even in South Korea, which has long been seen as a Christian "boom land", we can now observe (in the wake of dynamic modernization) a process of secularization, or at least an end to the growth of religious vitality (POLLACK; ROSTA, 2015, p. 382-400). Religious vitality here is also at a moderate level. These developments suggest not so much a general return of the religious and more a multi-dimensional shift in religious allegiances.

If there is a lack of evidence for a respiritualization of the population, then at least the socio-structural development of religious pluralization and the consequences associated with it can be cited as evidence of a return of religions (and less of the religious in general). Muslim migratory groups in particular have contributed to a visible religious pluralization in Europe. But it is not sufficient to speak of a return of religions solely on the basis of migration processes and socio-structural shifts. Immigration, for example, is still not enough in any Western European country to compensate for the collapses experienced by the Christian religion. We are now dealing here with the level of public discourse, for it seems the case that the migration movements have sparked new debates about religion. Casanova (1994) even sees an increase in the public importance of religion, which goes against the claim that it has lost its social importance. This leads him to make a radical criticism of secularization theory, which he classifies as a social myth (POLLACK, 2003) - that is, a false narrative.

17 This development can be extrapolated from data from the World Values Surveys, but can also be supported by other survey data. The American non-governmental organization PEW, which is very much concerned with religiosity in the US, also points to an increase in the group of the irreligious in the US and Latin America. 
An empirical view does not at first confirm this claim that there has been a massive increase in public debates about religion in Germany (OVERBECK, 2016, p. 350-351). At the same time, though, there has also been no massive collapse, as might have been expected according to secularization theory. Findings from a discourse analysis carried out by Overbeck (2016) show that the number of debates on religion has remained relatively constant since 1946. Even if the methodological approach responsible for these figures could be further extended in the future, we are hardly dealing here with regard to these data with a return of the religious. ${ }^{18}$ Even more interesting is another finding: in the last few decades, the focus of discussion has shifted more to conflicts and religious identity (BOCHINGER, 2012, p. 130; FOX, 2004). Above all, it is debates on and about Islam that have taken centre stage and that have contributed to the constant visibility of the debates (OVERBECK, 2016, p. 352-353). Religion has become an issue that primarily benefits from discourses about identity, the demarcation of identity, and allegiances (HIDALGO, 2016, p. 145-148; LIEDHEGENER, 2016, p. 68-69; PICKEL; YENDELL; JAECKEL, 2016, p. 116-117). However, changes in the social situation in Europe in the form of increasing religious pluralization would not alone lead to an expansion of discourse. Such an expansion comes about to begin with from subjective attitudes, assessments, and the resulting attitudes of people towards other religions and their members. These are heavily influenced by international public discourse - or, better, by discourses that deal with international developments (OVERBECK, 2016, p. 365).

18 Overbeck (2016) uses a corpus analysis to trace the development of the debates on religion in four major daily newspapers since 1946. 


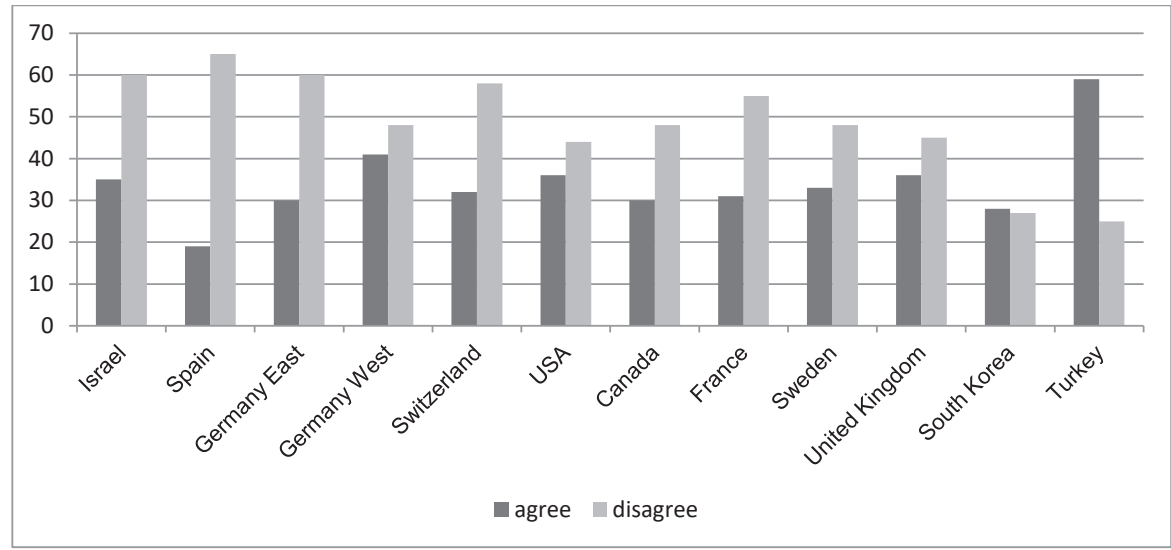

Figure 8 - Islam does fit in Western world - more refusal than support

Source: Own calculations; Bertelsmann Religionsmonitor 2013: "Islam does fit in Western world", in percent; positive answers (agree and totally agree).

This can be seen in Figure 8, where the citizens of 13 (not only European) countries regard Islam virtually across the board more often as "not belonging to the Western world" than the other way around. This assessment depends without doubt on the direct conditions on the ground (e.g., Israel). However, the wide range of countries in which this assessment is made seems to express the perception of a conflictual "struggle of cultures" (HUNTINGTON 1996; see also FOX, 2004 or HIDALGO 2016, p. 149-153), in which Islam is regarded as inapposite and alien. The view of Islam thereby differs from the view of Buddhism, Christianity, Judaism, and Hinduism (PICKEL, 2015, p. 27-29, p. 31; PICKEL; YENDELL; JAECKEL, 2016, p. 92; POLLACK et al., 2014, p. 18). What can we learn from this? Above all, that it is a discourse about a religion, as well as discussions shaped by conflict and a negative view of religion, that shape public perception. This supports the empirical finding that it is primarily group-related prejudices in the populations (DECKER et al., 2016; also QUILLIAN, 1995) that determine the discourse. By drawing on the study "Perception of Religious Diversity", Figure 9 shows the negative images associated with Islam in different European countries, with these focusing mainly on the potential for conflict, fanaticism, narrowmindedness, and the use of violence. In contrast, features of Islam such 
as peacefulness and solidarity are mentioned by only a few citizens in the countries investigated in relation to Islam. Besides the stereotype of violence and conflict, Islam is viewed as backward and pre-modern. ${ }^{19}$ This is most evident in the assessment of Islam as a religion that oppresses women. The stereotype of an a- or anti-modern Islam has implications for public behaviour towards Islam and Muslims. It serves even in enlightened circles as a means to criticize Islam without having to think twice about doing so, with people thereby being able to point to this anti-modern and non-liberal orientation of Islam, without immediately coming under suspicion of being a prejudiced "hater of Islam". Many traditional attitudes and values belonging to the representative behaviour of Muslim citizens inside and outside people's own countries do ultimately give them a reason to argue for such a position. But this becomes problematical if this attitude serves to legitimize discriminatory behaviour, as a close correlation between stereotypes and perceptions of threat (PICKEL; YENDELL, 2016, p. 293).

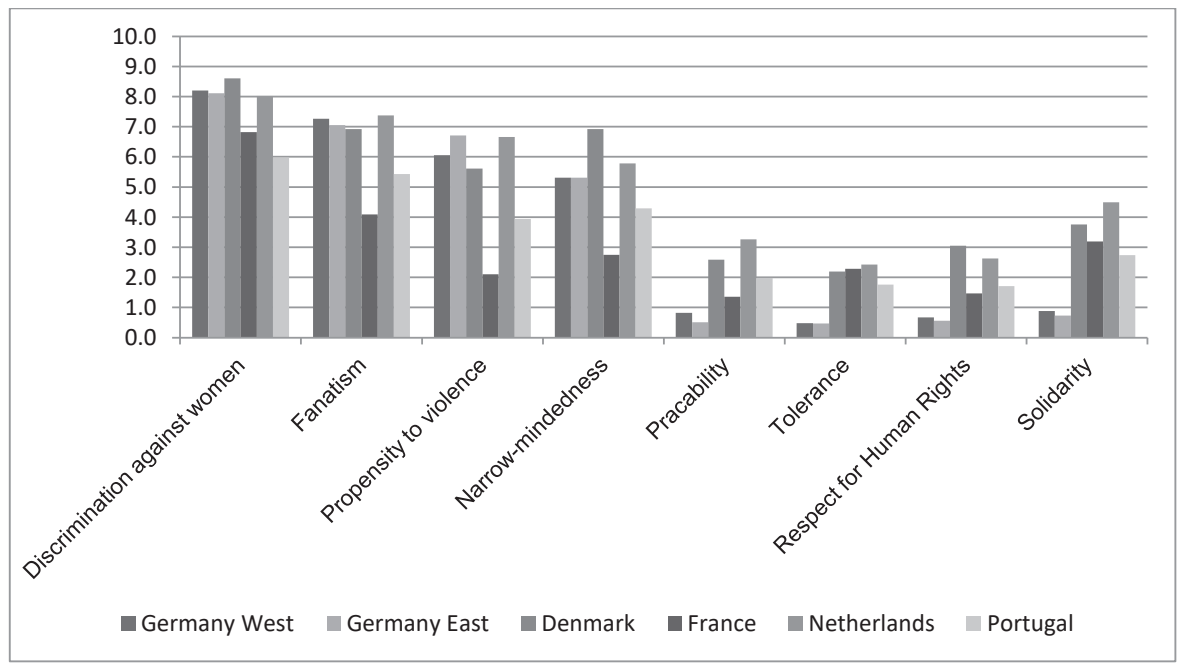

Figure 9 - Images of Islam - more negative than positive

Source: Wahrnehmung und Akzeptanz religiöser Vielfalt in der europäischen Bevölkerung (WARV) 2010; in percent; (see also POLLACK et al., 2014).

19 The assessment regarding Islam is thereby mirrored in the assessment of Christianity concerning the same statements (POLLACK et al., 2014, p. 23). 
These images and group-specific prejudices show a narrative of Islam that is common in the majority of European populations - and that has thereby changed the view of religion in the public domain. We are now coming closer to the narrative of the return of religion here - in the sense of a return of religions. It is borne by the narrative of the spread of a "dangerous Islam" or Islamism. The prejudices are based on the perception of "Islam" as dangerous - and as a threat to oneself and to one's own collective group. Just as allegiances play a role in perceptions, so also of relevance are real experiences of threats by members of a religion or a group associated with this religion. Such an explanation for high perceptions of threat is not very obvious in some areas of Europe - for East Germany, for example. Thus, attacks (and therefore the threat) can be attributed by citizens to all Muslims through a confusion of Islam and Islamic fundamentalists - but they do not have to make such an attribution. It is certainly possible to differentiate between radical groups and ordinary fellow citizens, or simply to assess the threat as being less serious.

Great importance is attached to the number of contacts between members of different religions (PICKEL; YENDELL, 2016, p. 291-293). The contact hypothesis (ALLPORT, 1954; PETTIGREW, 1998) claims that personal contacts and experiences usually improve understanding between different social groups. The case of East Germany, where very few Muslims live (0.6\% of the population), but where there is a very high feeling of threat, can be interpreted as a reinforcing example in the opposite direction, with the lack of personal contacts promoting a high sense of threat. It seems as though, in the absence of concrete personal contacts, experiences gained in other ways play a role for perceptions of threat. Where there is hardly any contact with persons of the Muslim faith possible, many citizens base their assessment of Muslims on the media and especially on the television. ${ }^{20}$ This mechanism is called para-social contact. As Hafez and Richter (2007) show in a media analysis, such experiences of contact with the media are predominantly negative. It is not surprising, then, when assessments of the group "Muslims" are rather unfavourable due to the media in an area where there is a low chance of real experiences. ${ }^{21}$ This also makes clear where the public discussion on religion,

20 By analyzing surveys, we can therefore identify television as the most important source of information.

21 "Media experiences" are transferred to members of the Muslim community who live in a region. 
which is used to argue for a return of religion(s), is moving: it primarily reflects the (predominantly critical) discourses in Europe against a particular religion - Islam. At the same time, however, this debate again produces or strengthens the positions in society against Islam - and religion.

Of course, not all assessments are carry-over effects: real dangers arising from Islamist terror groups increase perceptions of threat. However, the feeling of threat seems to succeed quite well in disengaging itself from these real scenarios of danger. It is also often mixed with classic xenophobia, cultural aversions, and ethnocentrism to create a global attitude of rejection and a perception of threats with regard to an ethnic-religious group. In contrast, Christianity is perceived in the Christianized countries of Europe as unthreatening (Figure 10). At the same time, religious allegiance and cultural proximity do not necessarily appear to be the only explanatory features for the absence of a feeling of threat, since Buddhism and Hinduism are rarely regarded as a threat (PICKEL; YENDELL; JAECKEL, 2016, p. 96-97). The point of reference for the perception of threat is Islam, which is why its significance for public discourse is obvious.

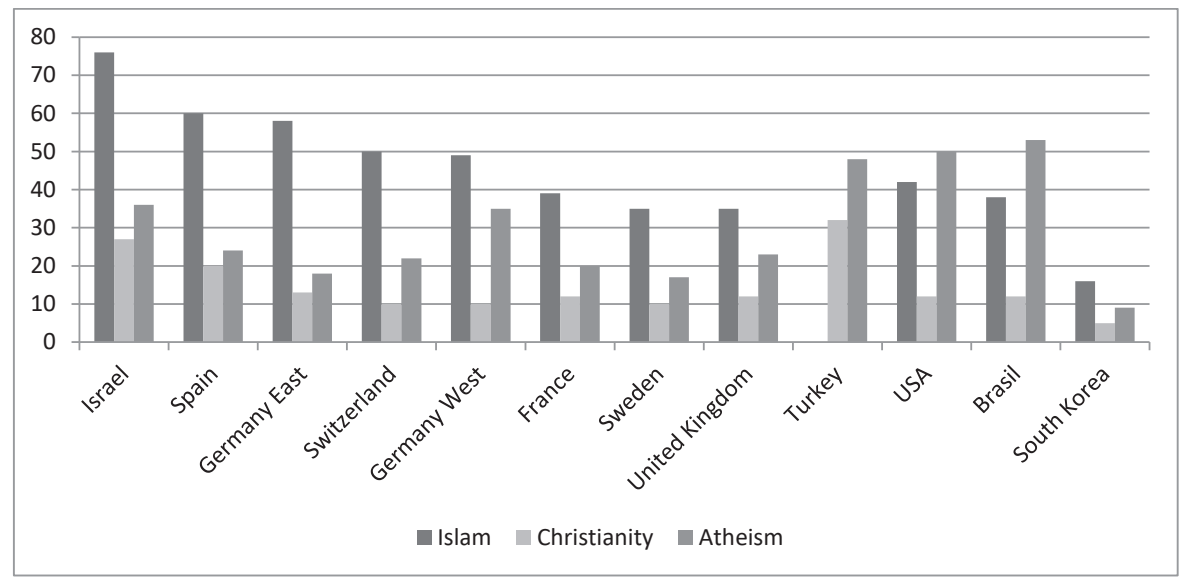

Figure 10 - Fear of Islam, Christianity and Atheism

Source: Own calculations; Bertelsmann Religionsmonitor 2013; "If you think on religions in the world: How much feel you threatened or enriched?"; in percent; persons who feel threatened; $n=1000-2000$. 
This also makes clear that the increase in the number of Islam-related discourses is primarily about discourses that deal with demarcation, identity of allegiance, and conflict. Discussions about God, one's own religiosity, or the positions taken by one's own church play a less important role, which corresponds entirely to the claims of secularization theory. Perhaps it is still conflicts between the religious and the non-religious that ensure public debates about controversial political issues. As far as assessments of Christians are concerned, such debates are relatively free of conflict. Even in East Germany, which is largely irreligious, the assessment of Christianity is hardly more unfavourable than it is in strongly religious West Germany or other comparable countries. There has apparently been a relaxation in the relationship between Christians and non-Christians, which is certainly due in part to the changed majority situation regarding West Germany. This contrasts with atheism. Although the majority of the population in many European countries has grown accustomed to atheists and atheism, sizeable groups of people still feel threatened by it. This applies to more than half of Brazilians, almost $50 \%$ of Americans and Turks, and almost a third of West Germans. They regard atheism as a threat. In addition to their otherness, the activities affecting the public domain of the new atheists play what is perhaps not an insignificant role in this attitude, which also characterizes the polarization between atheists and the highly religious in the US. But this polarization can also very well attract public attention in West Germany, too.

If we take the perception of a threat and the effect of media presentation together, then it becomes clear that the assessment of "Islam" and Muslims feeds on stereotypes that have emerged since 2001 through the combination of terrorism and Islam and a changed world situation. The resulting fear and angst about terrorism is largely projected onto Islam. The relatively low level of knowledge about Islam as a religion, reports of a lack of success in integration in one's own country, a "refugee crisis", and a diffuse link between Islam and conflict make the anxiety rise and thereby shape group-related prejudices. Discussions about Salafists or IS fighters from Western Europe bring this threat even closer to people. In this respect, there is an increasing need for a discourse on the attitude of religion as a producer of conflict, especially since migratory movements to Europe have brought with them additional fears linked to (threatening) contact with Muslims. These aspects of religious 
pluralization can be interpreted as indicating a return of religions (and less so of the religious) in the sense of an increasing concern with a greater variety of people of different faiths. The return, however, is concentrated on the area of public debates and political discourses - and is primarily determined by negative discussions about the potential for conflict and threat posed by a specific religion. Its members are often identified as a problem and factors of conflict. There are also occasionally transfers that make religion a general problem: it is fanatical, irrational, unpredictable, or at least a discourse blocker (KANTNER; OVERBECK, 2016). In this way, allegiances to religions and identities associated with them (identities ascribed by others) become the focus of interest. Differences in subjective religiosity, as they are emphasized again and again in the return of the religious, play a subordinate role. They are more important in the context of fanaticism within religious groups. It is in any case clear that a return of religions at the discursive level is likely to be at the expense of a return of religion at other levels of secularization.

\section{Conclusion - simultaneity with different weightings: secularization, pluralization, polarization, and politicization}

If we take the survey results that have been presented seriously, then we can expect in the Europe of the future a further spread of a secular understanding of life as well as a social loss of importance of religion - which corresponds to the first introductory thesis. We are dealing here with pathdependent developments, which take place at different (initial) stages of religious vitality or of secularity in the different European countries, but which almost all progress in the same direction towards a larger number of secular people (VOAS; DOEBLER, 2011; NORRIS; INGLEHART, 2004; PICKEL, 2009, 2011). It is above all the mixture of processes summarized as modernization that drives this development forward. Changes in values and the freedoms of individuals to make decisions resulting from individualization are the result of socio-structural modernization and lead to the social loss of importance of religion. Religious options are still often chosen in individual decisions, but we can see for Europe a steady increase in the individual's choice of the secular option for everyday life. Many people in European societies no longer need 
religion in order to live, from their point of view, a good, autonomous and "normal" life. We need to describe this process as secularization, as it describes the declining importance of religion in the organization of society, but also in the everyday life of many people. What is important here is that at this point in time we are far from talking about a secular Europe. Religion has neither completely lost its importance in Europe, and nor are the majority of its people non-religious - at least in most countries of Europe that is the case, if no longer in all. For it is not only East Germany that already has a majority of non-religious people. The existing diversity in European religiosity depends both on the level of modernization as well as on historico-cultural, denominational and underlying political conditions and pathways. Based on the very uniform development of such a process in almost all European countries (albeit with different tempos and different starting points), the narrative of secularization in Europe can draw on strong empirical evidence (POLLACK; ROSTA, 2015). ${ }^{22}$

The indications of a proliferation of public debates on religion as well as their increased importance in civil society that Casanova (2009) cites as evidence against secularization are only a limited argument against secularization. There is no doubt something to the fact that no comparable loss of importance of religion (comparable, for example, to the collapses in membership) has taken place at the level of public debates. If so, then we can speak here at the most only of a return of religion. However, this growing public debate on religion is not a sufficient argument for rejecting secularization theory. Secularization takes place at the other levels of society. These forms of secularization are then either independent of the public discussion on religion or are even in a negative relationship to public discourses of religion. ${ }^{23}$ Public interest in religion can therefore increase without processes of organizational, social and individual secularization becoming weaker. What speaks against a broad-ranging return of the religious among individuals is the fact that it is usually hostile debates

22 Even in the US or various countries of Latin America, which are often posited as counter-models for the European process of secularization, there is a continuous, but slow, decline in religious vitality.

23 This corresponds well with earlier reflections by Casanova (1994), who argued for the separation of secularization according to levels. In so doing, he examines the impact relationships between the potential levels of secularization. In addition. Casanova states a dependency on the contextual conditions, which he then reduces only to the market conditions of religions and their ability to adapt to the demands of civil society. 
or at least debates with a partly negative colouring that emerge in the public domain. These debates do not promote religious allegiance and religiosity, but rather problematize religious identity. This finding can be interpreted more sharply: the increase in controversial debates about the position of religion in society, its (special) rights, and the justification of religious arguments can be seen as indicating that the presence of religion in Western societies is no longer a matter of course. Taking account of religious positions in social discourse has become more controversial than it was just a few decades ago.

This increased need for discussion also explains the remarkable gain in the political significance of religious issues. The secularization process in Europe, and especially Western Europe, in the sense of a lower influence of religion and churches on society as a whole, and decreasing numbers of religious people, in no way undermines a political or politico-public significance. We might even be so bold as to say that the diverse processes of the social loss of importance of religion in Europe are a central motor for the stronger public and political debate on religion (ROY, 2010). As paradoxical as it may seem, secularization is then the starting point for a return of the religious - into public discourse. This involves a politicization - or re-politicization - of issues (Thesis 3) that are, or will be, connected with religion. On the one hand, these are moral questions, or questions that are concerned with one's own existence or life itself. They become issues for public discussion that can be the object of fierce debate. Just look at euthanasia, prenatal diagnostics, the Burka ban, and the ritual slaughter of animals. These examples point to an even more important line of discussion: the question of identity allegiances and social demarcation. Here, ascriptions of (religious) otherness are gaining in importance, and are then discharged into controversial and violent public discourses. Different attitudes can lead to a polarization in society - and have already done so in some places. This is not to say that there is not also in many people a relatively quiet normalization in their juxtaposition of religiosity and non-religiosity, or religious indifference (however we may call this). The answer to Thesis 2 is therefore still open.

Besides an increasing public and political discussion about religion, there is also (at least in Europe) a "creeping social loss of importance of religion". We can therefore not exclude from the outset a reactivation of (religious) identity for the future. However, in the face of the weakening of religious ties, religious 
knowledge, and simply of religious integrability, this seems unlikely. And, if so, such a reactivation would take place under conditions of polarization (ROY, 2010) that can lead to an intensified antagonism between secular and religious, but also between ethno-religious attributions of allegiance. The increasingly sharp disputes about religious pluralization in Europe that we can observe are an example of this. Since religious pluralization is the second safe prognosis for the future of Europe, the related processes of polarization and politicization justify the need to develop an independent religious politics (LIEDHEGENER; PICKEL, 2016).

All in all, we can say that, compared to the narrative of the return of religions, secularization is the empirically more convincing narrative. Nevertheless, we do not have to oppose the two narratives; there are also simultaneities in their validity. Not least, this empirical simultaneity has contributed to the long survival of both narratives - and will continue to do so in the future.

\section{References}

ALLPORT, G. The Nature of Prejudice. Cambridge: Perseus Books, 1971.

BOCHINGER, C. (Ed.). Religionen, Staat und Gesellschaft. Die Schweiz zwischen Säkularisierung und religiöser Vielfalt. Zürich: Verlag Neue Züricher Zeitung, 2012.

BRUCE, S. God is Dead. Secularization in the West. Oxford: University Press, 2002.

BURCHARDT, M.; WOHLRAB-SAHR, M. Multiple Secularities. Religion and Modernity in the Global Age - Introduction. International Sociology, v. 28, n. 6, p. 605-611, 2003.

BURCHARDT, M.; WOHLRAB-SAHR, M.; MIDDELL, M. (Ed.). Multiple Secularities beyond the West. Religion and Modernity in the Global Age. Boston: de Gruyter, 2015.

CASANOVA, J. Public Religions in the modern World. Chicago: University Press, 1994. Europas Angst vor der Religion. Berlin: BVA, 2009.

EISENSTADT, S. Multiple Modernities. Daedalus, v. 129, n. 1, p. 1-29, 2000.

FOX, J. Religion, Civilization, and Civil War. 1945 Trough the New Millennium. Lanham: Lexington Books, 2004.

FOX, J. Political Secularism, Religion, and the State. A Time Series Analysis of Worldwide Data. Cambridge: University Press, 2015. 
GLOCK, C. Religion and Society in Tension. Chicago: Rand McNally 1965.

HAFEZ, K.; SCHMIDT, S. Die Wahrnehmung des Islam in Deutschland. Gütersloh: Bertelsmann, 2015.

HEELAS, P.; WOODHEAD, L. The spiritual revolution. Why Religion is giving way to Spirituality. Oxford: University Press. 2005.

HIDALGO, O. Religionen in der Identitätsfalle? Politiktheoretische Überlegungen zur Ambivalenz religiöser Gemeinschaftsbildung. In: WERKNER, I.-J.; HIDALGO, O. (Ed.). Religiöse Identitäten in politischen Konflikten. Wiesbaden: Springer VS, 2016. p. 145-173. HUNTINGTON, S. P. The Clash of Civilizations and the Remaking of World Order. London: Simon \& Schuster, 1996.

KANTNER, C.; OVERBECK, M. Religiöse Identitäten als Diskursblocker. In: WERKNER, I.-J.; HIDALGO, O. (Ed.). Religiöse Identitäten in politischen Konflikten. Wiesbaden: Springer VS, 2016. p. 173-192.

LIEDHEGENER, A. Religiöse Identitäten als Problem wechselseitiger Identifizierungen und Kategorisierungen. Aktuelle theoretische Konzepte und Fragen ihrer Operationalisierung in der empirischen Religionsforschung. In: WERKNER, I.-J.; HIDALGO, O. (eds.). Religiöse Identitäten in politischen Konflikten. Wiesbaden: Springer VS, 2016. p. 65-82.

.; PICKEL, G. Religionspolitik und Politik der Religionen in Deutschland. Fallstudien und Vergleiche. Wiesbaden: Springer VS, 2016.

LOIS, D. Wenn das Leben religiös macht. Altersabhängige Veränderungen der kirchlichen Religiosität im Lebensverlauf. Wiesbaden: Springer VS, 2013.

LUCKMANN, T. The invisible Religion. The Problem of Religion in Modern Society. London: Macmillan, 1967.

MARTIN, D. A general theory of secularization. Oxford: University Press, 1978.

MEULEMANN, Heiner. Nach der Säkularisierung. Religiosität in Deutschland 19802012. Wiesbaden: Springer VS, 2015.

NORRIS, P.; INGLEHART, R. Sacred and Secular. Religion and Politics Worldwide. Cambridge: University Press, 2004.

OVERBECK, M. Die Rückkehr der Religion in die politische Öffentlichkeit? Eine computerlinguistische Exploration der deutschen Presse von 1946-2012. In: LEMKE, M.; WIEDEMANN, G. (Ed.). Text Mining in den Sozialwissenschaften. Grundlagen und 
Anwendungen zwischen qualitativer und quantitativer Diskursanalyse. Wiesbaden: Springer VS, 2016. p. 343-368.

QUILLIAN, L. "Prejudice as a Response to Perceived Group Threat: Population Composition and Anti-Immigrant and Racial Prejudice in Europe. American Sociological Review, v. 60, p. 586-611, 1995 .

PETTIGREW, T. F. Intergroup Contact Theory. Annual Review of Psychology, v. 49, p. 65-85, 1998.

PICKEL, G. Secularization as European fate? Results from the Church and Religion in an enlarged Europe project. In: PICKEL, G.; MÜLLER, O. (Ed.). Church and Religion in Contemporary Europe. Results from empirical and comparative research. Wiesbaden: VS-Verlag, 2009. p. 89-123.

. Contextual Secularization. Theoretical Thoughts and Empirical Implications.

Religion and Society in Central and Eastern Europe, v. 4, n. 1, p. 3-20, 2011.

Religionsmonitor 2013. Religiosity in international comparison. Gütersloh: Bertelsmann Stiftung, 2013.

. Religiöse Pluralisierung als Bedrohungsszenario? Stereotypen, Ängste und die Wirkung von Kontakten auf die Integration von Menschen anderer Religion. In: AMIRPUR, K.; WEIßE, W. (Ed.). Religionen, Dialog, Gesellschaft. Analysen zur gegenwärtigen Situation und Impulse für eine dialogische Theologie. Münster: Waxmann, 2015. p. 19-56.

Öffentlicher Bedeutungsgewinn von Religion und doch Säkularisierung?. In: ZAPF, H.; HIDALGO, O. (Ed.). Das Narrativ von der Wiederkehr der Religionen. Wiesbaden: Springer VS, 2017. p. 110-132.

. Religiosität in Deutschland und Europa - Religiöse Pluralisierung und Säkularisierung auf soziokulturell variierenden Pfaden. Zeitschrift für Religion, Gesellschaft und Politik, v. 1, n. 1, p. 37-74, 2017.

.; GLADKICH, A. Religious Social Capital in Europe. Connections between Religiosity and Civil Society. In: PICKEL, G.; SAMMET, K. (Ed.). Transformations of Religiosity: Religion and Religiosity in Eastern Europe 1989-2010. Wiesbaden: Springer VS, 2012, p. 69-94.

.; SAMMET, K. Transformations of Religiosity. Religion and Religiosity in Eastern Europe 1989-2010. Wiesbaden: Springer VS, 2012. 
.; YENDELL, A. Islam als Bedrohung? Beschreibung und Erklärung von Einstellungen zum Islam im Ländervergleich. Zeitschrift für Vergleichende Politikwissenschaft, v. 10, n. 3-4, p. 273-309, 2016. ; .; JAECKEL, Yvonne. Religiöse Pluralität als Bedrohung oder kulturelle Bereicherung? Die Wahrnehmung von Bedrohung durch Religion im Ländervergleich. In: WERKNER, I.-J.; HIDALGO, O. (Ed.). Religiöse Identitäten in politischen Konflikten, Wiesbaden: Springer VS, 2016. p. 83-122.

POLLACK, D. Säkularisierung - ein moderner Mythos?. Tübingen: Mohr Siebeck, 2003. Rückkehr des Religiösen?. Tübingen: Mohr Siebeck, 2009.

. Religion und gesellschaftliche Differenzierung. Tübingen: Mohr Siebeck, 2016. .; et al. (Ed.). Grenzen der Toleranz. Wahrnehmung und Akzeptanz religiöser Vielfalt in Europa. Wiesbaden: Springer VS, 2014.

.; MÜLLER, O.; PICKEL; G. The Social Significance of Religion in the Enlarged Europe. Secularization, Individualization and Pluralization. Farnham: Ashgate, 2012.

.; ROSTA, G. Religion in der Moderne. Ein internationaler Vergleich. Frankfurt/ Main: Campus, 2015.

PUTNAM, R. D. Bowling Alone. The Collapse and Revival of American Community. New York: Simon \& Schuster, 2000.

PUTNAM, R.; CAMPBELL D. E. American Grace: How Religion Unites and Divides us. New York: Simon \& Schuster, 2010.

ROY, O. Holy Ignorance. When Religion and Culture Part Ways. New York: Columbia, 2010 .

STARK, R. Secularization, R.I.P. Sociology of Religion, v. 60, n. 3, p. 249-273, 1999.

.; FINKE, R. Acts of Faith. Explaining the Human Side of Religion. Berkeley: University of California Press, 2000.

.; IANNACCONE, L. R. "A Supply-Side Reinterpretation of the 'Secularization' of Europe”. Journal for the Scientific Study of Religion, v. 33, n. 3, p. 230-252, 1994.

STOLZ, J. Explaining Religiosity. Towards a Unified Theoretical Model. British Journal of Sociology, v. 60, n. 2, p. 345-376, 2009. 
. et al. (Un)Believing in Modern Society. Religion, Spirituality, and Religious-Secular Competition. Abingdon: Routledge, 2016.

SWATOS, W. H.; CHRISTIANO, K. J. Secularization Theory. The Course of a Concept. Sociology of Religion, v. 60, n. 3, p. 209-228, 1999.

.; OLSON, D. V. The Secularization Debate. Lanham: Rowman \& Littlefield, 2000.

TRAUNMÜLLER, R. Religion und Sozialkapital. Ein doppelter Kulturvergleich. Wiesbaden: VS Springer, 2012.

TSCHANNEN, O. The Secularization Paradigm. A Systematization. Journal for the Scientific Study of Religion, v. 30, n. 4, p. 395-415, 1991.

VOAS, D. The continuing secular transition. In: POLLACK, D.; OLSON, D. V. (Ed.). The Role of Religion in Modern Societies. New York: Routledge, 2008. p. 25-48. .; DOEBLER, S. Secularization in Europe. Religious Change between and within Birth Cohorts. Religion and Society in Central and Eastern Europe, v. 4, n. 1, p. 39-62, 2011.

\section{Secularização - uma narrativa consolidada empiricamente diante de uma crescente influência da religião na política}

\section{Resumo}

Com esta pesquisa Gert Pickel propõe uma revisão atualizada da narrativa da secularização, contrapondo-a aos fenômenos crescentes de pluralização religiosa, polarização secular-religioso e politização da religiosidade. O artigo foca-se, sobretudo, no cenário religioso europeu de finais do século XX e inícios do século XXI, analisando os desenvolvimentos empíricos nos seus índices de secularização, nomeadamente ao nível individual. Para tanto o autor recorre a diversos dados estatísticos que consideram as atitudes das pessoas em face da religião, considerando os diferentes níveis de modernização, bem como as diversas vicissitudes histórico-culturais, religiosas e políticas dos países. $\mathrm{O}$ artigo conclui que, não obstante a proliferação dos assuntos religiosos no debate público, a secularização continua sendo empiricamente mais convincente do que a narrativa do regresso das religiões. Contudo, continuamos longe de poder falar de uma Europa secular.

Palavras-chave: Secularização. (Re)Politização do religioso. Europa.

Recebido em: 18/02/2017. Aprovado em: 16/03/2017. 